\title{
Recent records of endangered birds in the state of São Paulo, Southeastern Brazil
}

\author{
Shayana de Jesus ${ }^{1 *}$, Adriano César Buzzato ${ }^{2}$, Alexandre Bianco ${ }^{3}$, Evair Legal ${ }^{4}$, Fábio Gaio Chimentão ${ }^{5}$, \\ Márcio Coutinho Pelissari ${ }^{6}$ and Tiago João Cadorin ${ }^{7}$ \\ 1 IBILCE/UNESP, Programa de Pós-Graduação em Biologia Animal, CEP 15054-000, São José do Rio Preto, SP, Brazil. \\ 2 QI 18 bloco H apt 108. Bairro Guará, CEP 71015-084, Brasília, DF, Brazil. \\ 3 Rua: Projetada s/no- Bairro Pirago, CEP 88840-000, Urussanga, SC, Brazil. \\ 4 Rua Santa Cruz, 401. Bairro Águas Claras, CEP 88353-600, Brusque, SC, Brazil. \\ 5 Rua Engenheiro Alberto Monteiro de Carvalho, 36. Bairro Capão da Imbuia, CEP 82810-280, Curitiba, PR, Brazil. \\ 6 Rua Manife Tacla, 1270 - sobrado2. Pilarzinho, CEP 82120-310, Curitiba, PR, Brazil. \\ 7 Rua Adelina Zierke, 245. Bairro Águas Claras, CEP 88353-617, Brusque, SC, Brazil. \\ * Corresponding author. E-mail: shayanabio@gmail.com
}

\begin{abstract}
Here we report records of endangered birds in the state of São Paulo, based on the state list of Endangered Fauna. Our results were obtained during two field trips to survey and monitor the avifauna in eight farms in the southeastern, southwestern, and Midwestern regions of the state. Field work was conducted from October 25th to November 25th 2010 and from March 28th to April 28th 2011.
\end{abstract}

Brazil is the second richest country in bird species, with 1.832 species (CBRO 2011). However, 160 species are under threat currently, 98 of which occur in the Atlantic Forest (Silveira and Straube 2008). The major threats to the Brazilian avifauna are habitat loss, fragmentation, and excessive capture of specimens for illegal trade (Marini and Garcia 2005).

The state of São Paulo alone is home to about 793 species, representing approximately $45 \%$ of the Brazilian avifauna (Silveira and Uezu 2011). A total of 128 species were listed on the first state list of threatened birds (São Paulo 1998). The last update of the list contains 171 species, representing roughly $22 \%$ of the avifauna of the state (São Paulo 2008). The major factors threatening the avifauna of São Paulo are the degradation of natural environments, primarily due to the expansion of farming in the central and western regions, real estate development in areas of costal lowland forest, and contamination of watercourses (Silveira et al. 2009).

Here, we report records of endangered birds, based on the list of Endangered Fauna of the State of São Paulo (São Paulo 2008). Our results were obtained from nine localities of the southeastern, southwestern, and midwestern regions of the state of São Paulo (Table 1, Figure 1). Two field trips were done aiming to survey and monitor the avifauna in eight farms belonging to the Suzano Pulp and Paper Co. Also, sporadic records were obtained in the central area of São José dos Campos (CASJC). Field work was conducted from October 25th to November 25th 2010 and from March 28th to April 28th 2011. Each survey lasted 30 days, with three workdays in each sampling area.

The field sites were had different vegetation profiles. Parque das Neblinas (PN) and the farms Vitória (VF), Montes Claros (MCF), Cinco Nascentes (CNF), and Capanhão (CF) are covered by Rain Forest, whereas the Santana (SF), Entrerios (EF) and Brumado II (BF) farms are characterized by the transition between Mixed Atlantic
Rain Forest and Atlantic Rain Forest. Although the central area of São José dos Campos (CASJC) is greatly urbanized, parks, and woodlands are common. The climate in the farm Santana is classified as CFA according to Köppen, i.e., tropical climate with hot summers and no dry season. In the remaining sites, the climate is classified as CWA, i.e., high-altitude tropical climate with rainy summer and dry winters.

The farms Santana, Vitória, Montes Claros, and Parque das Neblinas have a mix of environments, with remnants of primary forest, fragments of secondary vegetation in early, intermediate, and advanced stages of regeneration, wetlands, rocky outcrop vegetation, and plantations of Eucalyptus. In Entrerios, Brumado II, and Capanhão hold remnants of primary forest, fragments of secondary vegetation at different succession stages, and Eucalyptus plantations. Cinco Nascentes has an extensive area of advanced secondary vegetation and Eucalyptus plantations.

We identified 13 endangered species (São Paulo 2008), one of them was critically endangered (CR) and 12 were vulnerable (VU). There were also nine species assigned as near threatened (NT) and one as data deficient (DD). The taxonomy and nomenclature of species listed below follow the Brazilian Ornithological Records Committee (CBRO 2011). Photos were only used to identify species when such records allowed an unambiguous identification. Some of the pictures and records that were made here are deposited at the public database Wikiaves while others are stored at the authors private database.

\section{Critically endangered - CR}

Sporophila frontalis (Verreaux, 1869) (Buffyfronted Seedeater): this species is endemic to the Atlantic Forest(Brooks etal.1999) and threatened by illegal capture, bird trade, and habitat degradation (Machado 2009a). Its distribution is very fragmented and its population is 


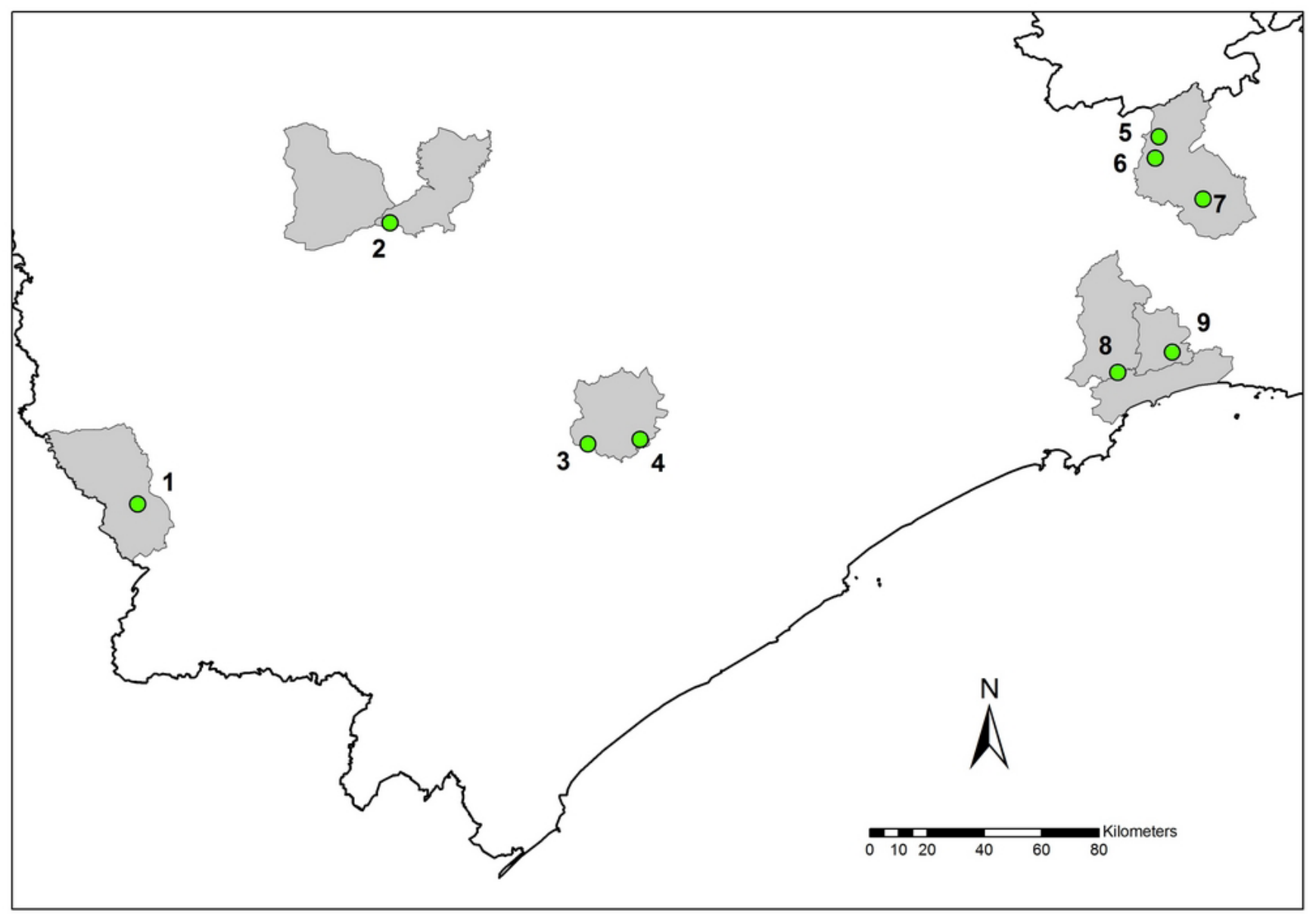

Figure 1. Map of the study area in the state of São Paulo, Brazil: 1. Santana Farm; 2. Entrerios Farm; 3. Brumado II Farm; 4. Vitória Farm; 5. Cinco Nascentes Farm; 6. Montes Claros Farm; 7. Central area of São José dos Campos; 8. Parque das Neblinas; 9. Capanhão Farm.

currently dwindling (Machado 2009a). On November 4th 2010, an audio record of the buffy-fronted seedeater was made at BF. On April 8th 2011, an individual was seen and its call was recorded (WA326810) while it moved through a grassland at BF. In the southern state of São Paulo, in the Serra de Paranapiacaba, bamboo flowerings attract many S. frontalis to areas where they were totally absent (Simões 2010). The species was previously recorded in some localities of the Serra de Paranapiacaba. In 1998, it was also recorded at Parque Estadual Intervales (PEI) (Willis and Oniki 2003), which is located in the municipalities of Guapiara, Ribeirão Grande, Sete Barras, Eldorado and Iporanga. In 2009 it was recorded at Parque Estadual Turístico do Alto Ribeira (PETAR), which is located in the municipalities of Apiaí and Iporanga (Antunes and Eston 2010). D. Bucci recently published a photo of a specimen taken at PEI (in the municipality of Ribeirão Grande) (http://www.wikiaves.com/503983). In São Miguel Arcanjo municipality it was recorded at the Parque Estadual Carlos Botelho (PECB) (CEO 2012; Antunes et al. 2013). Recent records were gathered by D. Bete, in the Tapiraí municipality (http://www.wikiaves.com/766712), and by D. Duarte, in the Piedade municipality (http://www. wikiaves.com/665761). Our record is the first record of $S$. frontalis for the municipality Pilar do Sul.

\section{Vulnerable species - VU}

Tinamus solitarius (Vieillot, 1819) (Solitary

Tinamou): this species is endemic to the Atlantic Forest
(Brooks et al. 1999) and has disappeared from much of the countryside of the state, due to deforestation and poaching (Willis and Oniki 2003). It depends on forested areas (Figueiredo 2009a). The solitary tinamou was recorded at VF (November 7th 2010), CF (November 19th 2010) and PN (November 23rd, 24th, and 25th 2010, and April 23rd 24th, and 25th 2011). There are no previous records for this species at the municipality of Pilar do Sul. However, T. solitarius was recorded before in other closer municipalities (Iperó, Iporanga, Itapetininga, Juquiá, Miracatu and Sete Barras) and at the conservation units PEI, PECB, PETAR, and EEcX (Estação Ecológica de Xitué) (Pacheco and Fonseca 2002; Pedrocchi et al. 2002; Figueiredo and Filho 2003; Willis and Oniki 2003; Antunes and Eston 2007; Antunes and Eston 2010; Antunes et al. 2013). Recent records were made at the municipality of Ibiúna by M. Merzvinskas (http://www.wikiaves. com/504811) and in Tapiraí, by E. Kaseker (http:// www.wikiaves.com/128179). This species was already registered by Donatelli et al. (2011). For this region, there are previous records from Ubatuba, Cubatão and Santos municipalities. Our record of T. solitarus is the first one for Biritiba Mirim, given that it was recorded before at the region, in Bertioga (Willis and Oniki 2003).

Pseudastur polionotus (Kaup, 1847) (Mantled Hawk): another endemic species to the Atlantic Forest (Brooks et al. 1999) extremely dependent on forested areas (Amaral 2009). The major threats to this species are 
TABLE 1. Locaties sampled in the state of São Paulo from October 25th to November 25th 2010 and from April 28 th to May 28 th 2011.

\begin{tabular}{llll}
\hline CODE & LOCATION & MUNICIPALITY & GEOGRAPHIC COORDINATES (WGS-84 DATUM) \\
\hline SF & Santana Farm & Itararé & $24^{\circ} 8^{\prime} 20.44^{\prime \prime} \mathrm{S}, 49^{\circ} 14^{\prime} 8.65^{\prime \prime} \mathrm{W}$ \\
$\mathrm{EF}$ & Entrerios Farm & Bofete/Itatinga & $23^{\circ} 15^{\prime} 18.64^{\prime \prime} \mathrm{S}, 48^{\circ} 26^{\prime} 33.30^{\prime \prime} \mathrm{W}$ \\
$\mathrm{BF}$ & Brumado II Farm & Pilar do Sul & $23^{\circ} 56^{\prime} 58.37^{\prime \prime} \mathrm{S}, 47^{\circ} 49^{\prime} 14.68^{\prime \prime} \mathrm{W}$ \\
$\mathrm{VF}$ & Vitória Farm & Pilar do Sul & $23^{\circ} 56^{\prime} 6.29^{\prime \prime} \mathrm{S}, 47^{\circ} 39^{\prime} 26.40^{\prime \prime} \mathrm{W}$ \\
$\mathrm{CNF}$ & Cinco Nascentes Farm & São José dos Campos & $22^{\circ} 59^{\prime} 6.29^{\prime \prime} \mathrm{S}, 46^{\circ} 1^{\prime} 34.35^{\prime \prime} \mathrm{W}$ \\
$\mathrm{MCF}$ & Montes Claros Farm & São José dos Campos & $23^{\circ} 3^{\prime} 8.07^{\prime \prime} \mathrm{S}, 46^{\circ} 9^{\prime} 21.31^{\prime \prime} \mathrm{W}$ \\
$\mathrm{CASJC}$ & Central Area & São José dos Campos & $23^{\circ} 10^{\prime} 49.77^{\prime \prime} \mathrm{S}, 45^{\circ} 53^{\prime} 18.71^{\prime \prime} \mathrm{W}$ \\
$\mathrm{PN}$ & Parque das Neblinas & Mogi das Cruzes/Bertioga & $23^{\circ} 43^{\prime} 28.83^{\prime \prime} \mathrm{S}, 46^{\circ} 9^{\prime} 21.31^{\prime \prime} \mathrm{W}$ \\
$\mathrm{CF}$ & Capanhão Farm & Biritiba Mirim & $23^{\circ} 39^{\prime} 39.99^{\prime \prime} \mathrm{S}, 45^{\circ} 59^{\prime} 2.07^{\prime \prime} \mathrm{W}$ \\
\hline
\end{tabular}

habitat loss, deforestation, and poaching (Amaral 2009). The mantled hawk was seen at MCF on November 12th and 13th 2010. One individual was photographed on the same site on April 13th 2011 (Figure 2A). Until a while ago, there were no documented records for $P$. polionotus at the region of the Vale do Paraíba (Willis and Oniki 2003; Lencioni Neto 2007). However, a recent record was made by M. Eugênio in the municipality of Monteiro Lobato (http://www.wikiaves.com/690761). Considering the available literature, our record of $P$. polionotus is the first for the municipality of São José dos Campos. Posteriorly, in 2012, M. Eugênio photographed the species in this municipality (www.wikiaves.com/822295).

Spizaetus tyrannus (Wied, 1820) (Black HawkEagle): the main threats to this species are habitat loss, fragmentation, poaching, and trafficking of its eggs and chicks (Granzinolli 2009). One individual was photographed (WA325666) and its call recorded at BF on April 6th 2011. It then landed on an Eucalyptus, after being attracted by the playback. This species was previously recorded in Iperó municipality and in the conservation areas PEI, PECB, PETAR and and EEcX (Pedrocchi et al. 2002; Figueiredo and Filho 2003; Willis and Oniki 2003; Antunes and Eston 2007; Antunes and Eston 2010; Antunes et al. 2013). Recent records were gathered by D. Bete in the municipality of Tapiraí (http://www.wikiaves. com/746695). The record of this species described at this work is the first of the municipality of Pilar do Sul.

Triclaria malachitacea (Spix, 1824) (Blue-bellied Parrot): endemic to the Atlantic Forest (Brooks et al. 1999). The main threats to this species are forest fragmentation, the illegal cutting of palm trees to extract palm heart, and the capture of specimens for wild animal traffic (Schunck and Benedicto 2009). The blue-bellied parrot was recorded at VF (November 8th 2010) and at BF (April 9th 2011) (WA326801). This is also the first occurrence recorded in the municipality of Pilar do Sul. In this region, T. malachitacea was previously recorded at PEI, PECB, PETAR and EEcX, and in the municipalities of Juquiá, Miracatu and Sete Barras (Pedrocchi et al. 2002; Willis and Oniki 2003; Schunck and Benedicto 2009; Antunes and Eston 2007; Antunes and Eston 2010; Antunes et al. 2013). Recently, F. Manfredini recorded this species in São Miguel Arcanjo municipality (http://www. wikiaves.com/659559) and G. Serpa in Ribeirão Grande, at PEI (http://www.wikiaves.com/969125).

Polytmus guainumbi (Pallas, 1764) (White-tailed
Goldenthroat): the main threats to this species are habitat loss, especially marshes, wetlands, and woodland savanna (Sigrist 2006). The white-tailed goldenthroat was seen at PN on November 24th 2010, and one individual was photographed on April 27th 2011 at CASJC (Figure 2B). Usually found at the interior of the state (i.e., Midwest and Northeast portions, at steppe areas and at State Semidescidual Forests), this species inhabits flooded fields, shrub-savannas, cerrados, fresh water swamps and the proximity of streams (Willis and Oniki 2003). Recently, $P$. guainumbi has been expanding its distribution, being also registered at areas of Dense Ombrophilous Forest. For example, Willis and Oniki (2003) mentioned the presence of $P$. guainumbi at Serra da Mantiqueira, municipality of Taubaté, while Simpson et al. 2012 registered the species at Ubatuba. Therefore, our records of $P$. guainumbi at PN and at CASJC are one of the few for regions of Dense Ombrophilous Forest. It is noteworthy that the species was previously photographed by M. Crozariol (http://www. wikiaves.com/116452) in an area of lower vegetation with swampy patches of São José dos Campos. Our record, carried out in 2011, confirms the permanence of this species at this region.

Pteroglossus bailloni (Vieillot, 1819) (Saffron Toucanet): endemic to the Atlantic Forest (Brooks et al. 1999), this species depends on forested habitats and is a target of the illegal bird trade (Figueiredo 2009b). Its populations are small in the state (Figueiredo 2009b). The saffron toucanet was seen at BF (November 3rd and 4th, 2010), MCF (November 12nd, 2010) and PN (November 24th, 2010). This is the first record of this species for Pilar do Sul municipality. However, in this region, it has been previously recorded at PEI, PECB and PETAR, and in the municipalities of Alambari, Iporanga, Juquiá, Miracatu and Sete Barras (Pedrocchi et al. 2002, Figueiredo and Filho 2003, Willis and Oniki 2003; Antunes and Eston 2010; Antunes et al. 2013). In the Vale do Paraíba, our record is the first documented for São José dos Campos. But there are records of P. bailloni for the municipality of Caraguatatuba (Willis and Oniki 2003) and R. Fortes recorded this species in Santo Antônio do Pinhal municipality (http://www.wikiaves.com/22393). Donatelli et al. (2011), in an avifaunal survey at PN, did not record the occurrence of $P$. bailloni. Therefore, this is the first record of this Ramphastidae species for the PN. However, at the region of Atlantic Forest, near to the Park, the species was previously recorded in the municipalities of Santos and Ubatuba (Willis and Oniki 2003). 
Myrmotherula unicolor (Ménétriès, 1835) (Unicolored Antwren): it is found exclusively in the Atlantic Rain Forest, which suffers from habitat destruction and fragmentation, especially in lowland forests and restinga (steppe vegetation) (Schunck 2009a). In the State of São Paulo, M. unicolor is restricted to eastern forests, ranging from the north coast to the south coast. This species lives in lowland and hillside high forests, reaching up to $500 \mathrm{~m}$, being occasionally recorded in higher areas, up to $800 \mathrm{~m}$ high (Schunk 2009a). On April 20th, 2011, a male was captured and ringed at CF (Figure 2C). Given the available literature, our record is inedited for the municipality of Biritiba Mirim. It is worth to note that the local altitude is of approximately $780 \mathrm{~m}$. At the high areas of Serra do Mar, the records of this species are scarce, having a historical record (1963) in Reserva Biológica do Alto da Serra de Paranapiacaba, Santo André (Silveira 2009), located at an altitude between 750 to 900 $\mathrm{m}$. Documented records of $M$. unicolor at the nearby region of Biritiba Mirim are more common at the coastal plains, as mentioned by Willis and Oniki (2003) for the municipality of Bertioga.

Onychorhynchus swainsoni (Pelzeln, 1858) (Atlantic Royal Flycatcher): endemic to the Atlantic Forest (Brooks et al. 1999). It is restricted to eastern forests and to a few areas in the countryside of the São Paulo state, such as Teodoro Sampaio and Bauru (Willis and Oniki 2003). The main threats to this species are habitat loss and forest fragmentation, especially in costal lowland forests (Schunck 2009b). The Atlantic royal flycatcher was recorded at VF, where one individual was captured and ringed on November 9th, 2010 (Figure 2D), and another was photographed on April 7th, 2011 (WA326062). One individual was captured and ringed at CF on November 19th, 2010. The same individual was recaptured at $\mathrm{CF}$, and along with another specimen, which was also ringed. This is first record of occurrence of this species for Pilar do Sul municipality. In this region, there were records of $O$. swainsoni at PEI, PECB and PETAR, and in the municipalities of Ibiúna, Piedade and Sete Barras (Pedrocchi et al. 2002; Figueiredo and Filho 2003; Willis and Oniki 2003; Antunes and Eston 2010; Antunes et al. 2013). Our record of $O$. swainsoni also is the first record for Biritiba Mirim municipality. There was one documented record of this species in Cubatão municipality (Willis and Oniki 2003), a region of Atlantic Forest near to Biritiba Mirim.

Procnias nudicollis (Vieillot, 1817) (Bare-throated Bellbird): endemic to the Atlantic Forest (Brooks et al. 1999). Habitat loss and illegal bird trade are the major threats this species (Figueiredo 2009c). The bare-throated bellbird is a fruit-eating species and feeds its chicks with fruit (Magalhães 1999). For this reason, it is very sensitive to environmental changes (Magalhães 1999). However, like other frugivorous birds, it has great dispersal ability, moving to nearby fragments to search for food (Willis 1979) and, therefore, can be commonly found in forest fragments located next to large forested areas or even in urban areas (Santos 2010). The species was recorded at BF (November 3rd, 4th and 5th, 2010), VF (November 7th, 8th and 9, 2010), and PN (November 23rd, 24th and 25 th, 2010). In the region near to Pilar do Sul municipality, this species has been previously recorded at PEI, PECB, PETAR and EEcX (Pacheco and Fonseca 2002; Pedrocchi et al. 2002; Figueiredo and Filho 2003; Willis and Oniki 2003; Antunes and Eston 2007; Antunes and Eston 2010; Antunes et al. 2013), and in the municipalities of Alambari, Buri, Iperó, Itapetininga, Juquiá and Sete Barras (Willis and Oniki 2003). At PN, P. nudicollis was recorded by Donatelli et al. (2011), and in this region there were records of species occurrence in the municipalities of Bertioga, Cubatão, Ubatuba and Rio Grande da Serra (Willis and Oniki 2003).

Pyroderus scutatus (Shaw, 1792) (Red-ruffed Fruitcrow): endemic to the Atlantic Forest (Brooks et al. 1999). Habitat loss and isolation of populations in highly fragmented areas of the state are leading to its extinction in several regions (Develey and De Luca 2009). The redruffed fruitcrow was recorded at BF (November 3rd, 4th and 5th, 2010), VF (November 7th, 8th and 9th, 2010, and April 11st, 2010) (WA336677), CNF (November 15th, 2010), CF (November 19th, 2010, and April 20, 2011), CF (November 20, 2010), and PN (November 25th, 2010). According to available literature, our record for $P$. scutatus is the first one for the municipality of Pilar do Sul. However, this species was already registered in PEI, PECB and PETAR and in the municipalities of Alambari, Iperó, Juquiá, Miracatu and Sete Barras (Pedrocchi et al., 2002; Figueiredo and Filho 2003; Willis and Oniki 2003; Develey and De Luca 2009; Antunes and Eston 2010; Antunes et al. 2013). Although this species was found at the municipalities of Bertioga, Ubatuba and Cubatão (Willis and Oniki 2003), our record appears to be the first one that is documented for Biritiba Mirim, which is next to the mentioned municipalities. On the other hand, the occurrence of this species was previously documented for the municipality of São José dos Campos (Willis and Oniki 2003) and for PN (Donatelli et al. 2011).

Cyanoloxia moesta (Hartlaub, 1853) (Blackishblue Seedeater): endemic to the Atlantic Forest (Brooks et al. 1999). It is a poorly known, rare species (Machado 2009 b). Its population is decreasing, probably due to habitat loss and degradation (Machado 2009b). Like Sporophila frontalis, this species also converges to areas where bamboos are fructifying (Sick 1997). However, until this moment, there are no studies attesting this migration. Lopes et al. (2011) studied the seasonal distribution of the Blackish-Blue Seedeater and encountered no evidences for high scale or locally regularly movements. Nevertheless, they affirm that the hypothesis of nomad movements may not be refuted. The calling of this species was heard by T.J. Cadorin at the SF on November 27th, 2010. Notwithstanding, the observer is very familiarized with this call: "somewhat variable song a bright and spirited warbling (Ridgley and Tudor 2009)". Our record of $C$. moesta in Itararé is important to the region, as the only record for this municipality was done in 1984 (Wiilis and Oniki 2003). In this region, there is a documented record for the municipality of Jaguariaíva, state of Paraná (Straube et al.2005). Other records of $C$. moesta are located 
at the south and southeastern regions of the state of São Paulo (Machado 2009b). Recently, R.D. Rosa photographed the species in São José dos Campos (http://www.wikiaves. com/664841).

\section{Euphonia chalybea (Mikan, 1825) (Green-throated} Euphonia): endemic to the Atlantic Forest (Brooks et al. 1999). Its occurrence is restricted to the Atlantic Rainforest of São Paulo, and to a few regions in the countryside (Schunck 2009c). The main threats to this species are habitat loss and forest fragmentation, especially of costal lowland forests (Schunck 2009c). The calling of this species was heard by E. Legal at the FB on April 7th, 2011. It was not possible to record the call. Notwithstanding, the observer is familiarized with this vocalization, which is emitted under a quick way, similarly to a hooded siskin (Sporagra magellanica), being considerably monotonous and, usually, with no imitations (Sick 1997). This is first record of this species occurrence for Pilar do Sul municipality. In this region, it was previously recorded at PEI, PECB and PETAR (Willis and Oniki 2003; Schunck 2009c) and in the municipalities of Iperó and Sete Barras (Willis and Oniki 2003; Antunes and Eston 2010; Antunes et al. 2013).

Nine species considered near threatened (NT) and one data deficient (DD) were also recorded (Table 2). The DD species was the Buff-fronted Owl (Aegolius harrisii (Cassin, 1849)), recorded at SF, Itararé, on November 27th, 2010 (WA275252). A. harrisii was previously recorded at seven localities in the state: Osasco (Willis and Oniki 2003; Ribas and Santos 2007), Ribeirão Grande, Mogi das Cruzes (Ribas and Santos 2007), Tapiraí / São Miguel Arcanjo (Lima and Salles 2008), Lençóis Paulista, Avaré, and Franca (Ubaid et al. 2011). Specific studies are needed to assess the conservation status of their populations in the state (Silveira et al. 2009).

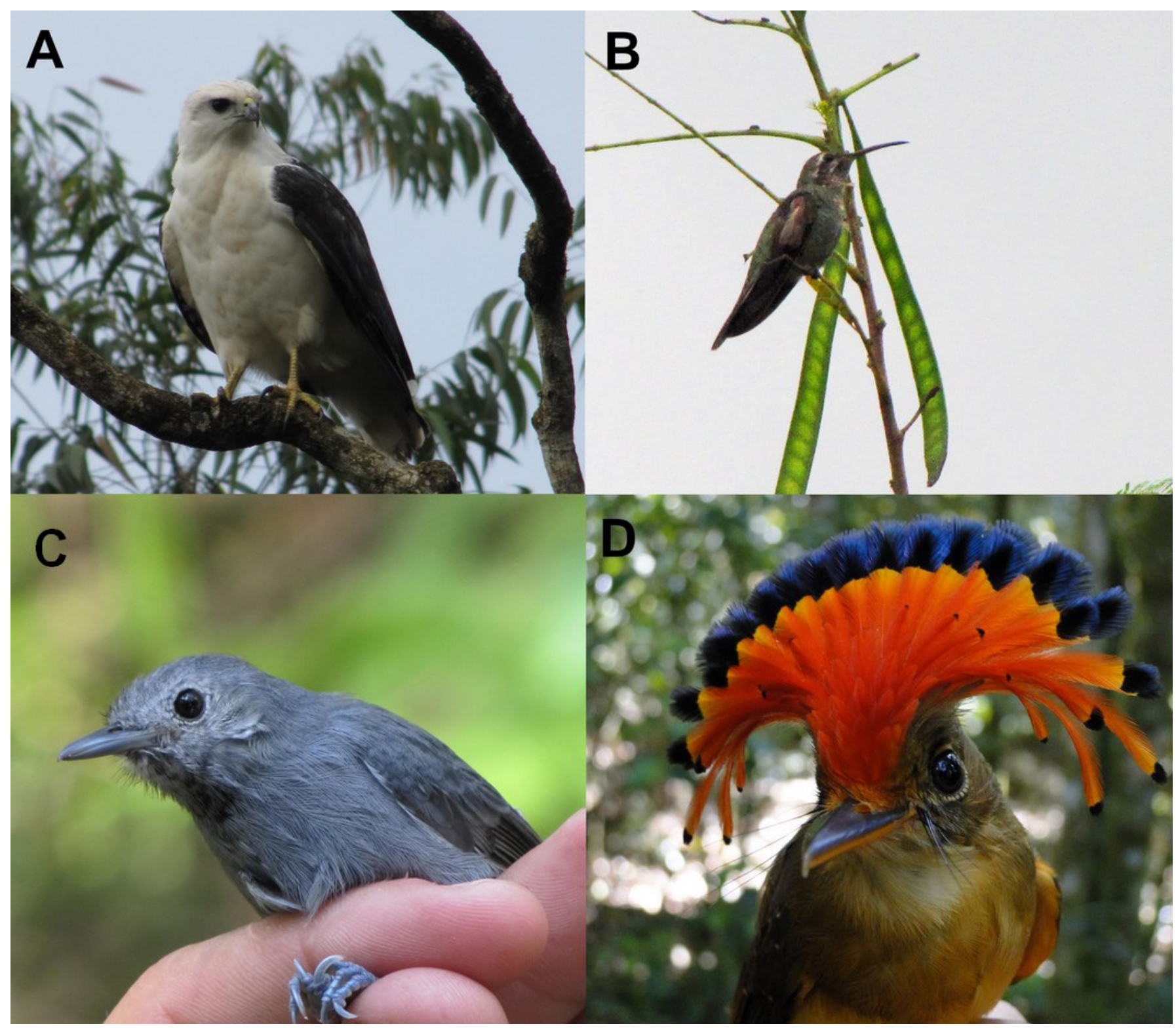

FiguRE 2. A. Pseudastur polionotus recorded in Montes Claros Farm on April 13th 2011 (Evair Legal); B. Polytmus guainumbi recorded in São José dos Campos on April 27th, 2011 (Evair Legal); C. Myrmotherula unicolor mist-netted in Capanhão Farm on April 20th, 2011 (Evair Legal); D. Onychorhynchus swainsoni mist-netted in Vitória Farm on November 9th, 2010 (Tiago João Cadorin). 
TABLE 2. Species assigned statewide to near threatened (NT) according to the list of Endangered Fauna of the State of São Paulo. Records: vc = visual contact; ac = audio contact; $\mathrm{mn}$ = bird captured with mist net; $\mathrm{pr}$ = photo record; $\mathrm{sr}$ = sound record (bird call).

\begin{tabular}{|c|c|c|}
\hline SPECIES & SITES (MONTH/YEAR OF RECORDS) & RECORDS \\
\hline Penelope obscura Temminck, 1815 & $\begin{array}{l}\text { SF }(25 / 10 / 2010,30 / 03 / 2011), \mathrm{EF}(31 / 10 / 2010), \mathrm{VF}(08 / 11 / 2010), \mathrm{BF} \\
(07 / 04 / 2011), \mathrm{MCF}(14 / 11 / 2010,15 / 04 / 2011), \mathrm{CNF}(27 / 04 / 2011), \mathrm{PN} \\
(25 / 04 / 2011)\end{array}$ & ac, vc, pr \\
\hline Chondrohierax uncinatus (Temminck, 1822) & PN (21/11/2010) & $\mathrm{vc}, \mathrm{pr}$ \\
\hline Hydropsalis forcipata (Nitzsch, 1840) & $\mathrm{EF}(04 / 04 / 2011), \mathrm{CF}(19 / 11 / 2010)$ & vc, pr \\
\hline Campephilus robustus (Lichtenstein, 1818) & VF $(08 / 11 / 2010)$ & ac \\
\hline Dysithamnus stictothorax (Temminck, 1823) & $\mathrm{BF}(07 / 04 / 2011)$ & ac \\
\hline Drymophila ochropyga (Hellmayr, 1906) & $\mathrm{BF}(08 / 04 / 2011), \mathrm{MCF}(15 / 04 / 2011), \mathrm{CF}(20 / 04 / 2011), \mathrm{PN}(23 / 11 / 2010)$ & $\mathrm{vc}, \mathrm{ac}, \mathrm{mn}$ \\
\hline Merulaxis ater Lesson, 1830 & CF $(20 / 11 / 2010)$, PN (25/04/2011) & ac, sr \\
\hline Anumbius annumbi (Vieillot, 1817) & $\mathrm{EF}(01 / 04 / 2011)$ & $\mathrm{vc}, \mathrm{pr}$ \\
\hline Gnorimopsar chopi (Vieillot, 1819) & CNF $(15 / 11 / 2010,14 / 04 / 2011)$ & ac \\
\hline
\end{tabular}

ACKNowledgments: We would like to thank Suzano Pulp and Paper Co. for providing us access to its areas. André Magnani Xavier de Lima and Daniele Cristina Pries Staut for their logistic support. Greg, for his support during the first field trip. Cristiano, Diogo, Fábio, Hamilton, Elso, and Ângelo from Loyal Serviços Especializados Ltda. for the escort provided to us and for their support during the field trips, and also Carlyle Sguassabia, Denilson Carvalho, Danilo Capela, and Orlando Pelissari Negreiros for their friendship and field support. Fernando Costa Straube, Luiz Fernando Figueiredo, Leonardo Esteve Lopes and Tomaz Nascimento de Melo, for help with information and bibliography. Daniel Duarte, Demis Bucci, Douglas Bete, Emerson Kaseker, Fábio Manfredini, Guilherme Serpa, Marco Crozariol, Marcos Eugênio, Mauricio Merzvinskas, Rafael Fortes and Rodrigo Dela Rosa gently provided data on records and authorized their citation in this work. Diogo Borges Provete and Pedro Henrique Pereira Braga revised the English version. And the referees made valuable comments on the manuscript.

\section{Literature Cited}

Amaral, F.S.R. 2009. Leucopternis polionotus; pp. 134, in: P.M. Bressan, M.C.M. Kierulff and A.M. Sugieda (org.). Fauna ameaçada de extinção no Estado de São Paulo - Vertebrados. São Paulo: Fundação Parque Zoológico de São Paulo e Secretaria do Meio Ambiente.

Antunes, A.Z. and M.R. Eston. 2007. Aves endêmicas e ameaçadas de extinção da Estação Ecológica de Xitué e a contribuição do taquaruçu Guadua tagoara (Nees) Kunth para a riqueza local. Revista do Instituto Florestal 19(2): 201-213.

Antunes, A.Z. and M.R. Eston. 2010. Riqueza e conservação da avifauna do Parque Estadual Turístico do Alto Ribeira-PETAR, SP. Revista do Instituto Florestal 22 (1): 133-154.

Antunes, A.Z., B.G. Silva, C.K. Matsukuma, M.R. Eston and A.M.R. Santos. 2013. Aves do Parque Estadual Carlos Botelho - SP. Biota Neotropica 13(2): 124-140.

Brooks, T., J. Tobias and A. Balford.1999. Deforestation and Bird Extinction in the Atlantic Forest. Animal Conservation 2: 211-222.

CBRO - Comitê Brasileiro de Registros Ornitológicos. 2011. Listas das aves do Brasil. 10 a Edição. Electronic Database accessible at http:// www.cbro.org.br/. Captured on 04 December 2011.

CEO - Centro de Estudos Ornitológicos. 2012. Levantamento de Avifauna em Unidades de Conservação do Estado de São Paulo. [Parque Estadual de Carlos Botelho]. Electronic Database accessible at http://www.ceo.org.br/avifest.htm/. Captured on 24 May 2013.

Develey, P. and A. De Luca. 2009. Pyroderus scutatus; pp. 234, in: P.M. Bressan, M.C.M. Kierulff and A.M. Sugieda (org.). Fauna ameaçada de extinção no Estado de São Paulo - Vertebrados. São Paulo: Fundação Parque Zoológico de São Paulo e Secretaria do Meio Ambiente.

Donatelli, R.J, C.D. Ferreira and T.V.V. Costa. 2011. Avian communities in woodlots in Parque das Neblinas, Bertioga, São Paulo, Brazil. Revista Brasileira de Biociências 09: 187-199.

Figueiredo, L.F.A. 2009a. Tinamus solitarius; pp. 102, in: P.M. Bressan, M.C.M. Kierulff and A.M. Sugieda (org.). Fauna ameaçada de extinção no Estado de São Paulo - Vertebrados. São Paulo: Fundação Parque Zoológico de São Paulo e Secretaria do Meio Ambiente.

Figueiredo, L.F.A. 2009b. Pteroglossus bailloni; pp. 197, in: P.M. Bressan, M.C.M. Kierulff and A.M. Sugieda (org.). Fauna ameaçada de extinção no Estado de São Paulo - Vertebrados. São Paulo: Fundação Parque Zoológico de São Paulo e Secretaria do Meio Ambiente.

Figueiredo, L.F.A. 2009c. Procnias nudicollis; pp. 232, in: P.M. Bressan, M.C.M. Kierulff and A.M. Sugieda (org.). Fauna ameaçada de extinção no Estado de São Paulo - Vertebrados. São Paulo: Fundação Parque Zoológico de São Paulo e Secretaria do Meio Ambiente.

Figueiredo, L.F.A. and A.C. Filho. 2003. Aves observadas em Unidades de Conservação do Estado de São Paulo por Antonio Flávio Barbosa.
Boletim CEO: 30-43.

Granzinolli, M.A.M. 2009. Spizaetus tyrannus; pp. 142, in: P.M. Bressan, M.C.M. Kierulff and A.M. Sugieda (org.). Fauna ameaçada de extinção no Estado de São Paulo - Vertebrados. São Paulo: Fundação Parque Zoológico de São Paulo e Secretaria do Meio Ambiente.

Lencioni Neto, F. 2007. Aves; pp. 138-156, in: P.C. Ferreira (coord.). A Biologia e a Geografia do Vale do Paraíba: Trecho Paulista. São José dos Campos: Iepa.

Lima, B. and O. Salles. 2008. Novo registro documentado do caburéacanelado (Aegolius harrisii) para o Estado de São Paulo. Atualidades Ornitológicas 143: 23.

Lopes, L.E., J.B. Pinho and C.E.R.T. Benfica. 2011. Seasonal Distribution and Range of the Blackish-Blue Seedeater (Amaurospiza moesta): A Bamboo-Associated BirdThe Wilson Journal of Ornithology 123(4): 797-802.

Machado, E. 2009a. Sporophila frontalis; pp. 253, in: P.M. Bressan, M.C.M. Kierulff and A.M. Sugieda (org.). Fauna ameaçada de extinção no Estado de São Paulo - Vertebrados. São Paulo: Fundação Parque Zoológico de São Paulo e Secretaria do Meio Ambiente.

Machado, E. 2009b. Amaurospiza moesta; pp. 266, in: P.M. Bressan, M.C.M. Kierulff and A.M. Sugieda (org.). Fauna ameaçada de extinção no Estado de São Paulo - Vertebrados. São Paulo: Fundação Parque Zoológico de São Paulo e Secretaria do Meio Ambiente.

Magalhães, J. C. R. 1999. As aves na Fazenda Barreiro Rico. São Paulo: Editora Plêiade. 215 pp.

Marini, M. A. and F. I. Garcia. 2005. Conservação de aves no Brasil. Megadiversidade 1: 95-102.

Pacheco, J.F. and P.S.M. Fonseca. 2002. Resultados de excursão ornitológica a determinadas áreas dos estados de São Paulo, Santa Catarina e Rio Grande do Sul em janeiro, 1990. Atualidades Ornitológicas 106: 3-5.

Pedrocchi, V., C.R. Silva and A. Silva. 2002. Check list of birds and mammals in the Paranapiacaba forest fragment; p. 183-204, in: E. Mateos, J.C. Guix, A. Serra and K. Pisciotta (ed.) Censuses of Vertebrates in a Brazilian Atlantic Rainforest Area: the Paranapiacaba Fragment. Barcelona: Universitat de Barcelona.

Ribas, C. F. and R.E.F. Santos. 2007. Novo registro documentado do caburéacanelado Aegolius harrisii iheringi (Sharpe, 1899) para o Estado do Paraná. Atualidades Ornitológicas 140: 4-5.

Ridgely, R.S. and G. Tudor. 2009. Field Guide to the Songbirds of South America: The Passerines. Austin: University of Texas Press. 750 pp.

São Paulo (Estado). Secretaria de Estado do Meio Ambiente. 1998. Fauna ameaçada no Estado de São Paulo. São Paulo: Série Documentos Ambientais.

São Paulo (Estado). 2008. Decreto Estadual № 53.494 de 2 de outubro de 2008. Declara as Espécies da Fauna Silvestre Ameaçadas, as Quase Ameaçadas, as Colapsadas, as Sobre-explotadas, as Ameaçadas de Sobre-explotação e com dados insuficientes para avaliação no Estado de São Paulo e dá providências correlatas. Diário Oficial do Estado de São Paulo seção 1,118 (187): 1-10.

Santos, A.S.R. 2010. Registro documentado da araponga Procnias nudicollis (Vieillot, 1817) no Jardim Botânico de São Paulo - Brasil. Electronic Database accessible at http://www.aultimaarcadenoe. com.br/wp-content/uploads/2011/08/2 Registro-documentadoda-araponga-no-Jardim-Bot\%C3\%A2nico-SP-AS.pdf/. Captured on 03 June 2013.

Schunck, F. 2009a. Myrmotherula unicolor; pp. 206, in: P.M. Bressan, M.C.M. Kierulff and A.M. Sugieda (org.). Fauna ameaçada de extinção no Estado de São Paulo - Vertebrados. São Paulo: Fundação Parque Zoológico de São Paulo e Secretaria do Meio Ambiente.

Schunck, F. 2009b. Onychorhynchus swainsoni; pp. 229, in: P.M. Bressan, M.C.M. Kierulff and A.M. Sugieda (org.). Fauna ameaçada de extinção no Estado de São Paulo - Vertebrados. São Paulo: Fundação Parque 
Zoológico de São Paulo e Secretaria do Meio Ambiente.

Schunck, F. 2009c. Euphonia chalybea; pp. 272, in: P.M. Bressan, M.C.M. Kierulff and A.M. Sugieda (org.). Fauna ameaçada de extinção no Estado de São Paulo - Vertebrados. São Paulo: Fundação Parque Zoológico de São Paulo e Secretaria do Meio Ambiente.

Schunck, F. and G.A. Benedicto. 2009. Triclaria malachitacea; p. 173 In P.M. Bressan, M.C.M. Kierulff and A.M. Sugieda (Org.). Fauna ameaçada de extinção no Estado de São Paulo - Vertebrados. São Paulo: Fundação Parque Zoológico de São Paulo e Secretaria do Meio Ambiente.

Sick, H. 1997. Ornitologia brasileira. Rio de Janeiro: Editora Nova Fronteira. 912 pp.

Sigrist, T. 2006. Aves do Brasil: uma visão artística. São Paulo: Avis Brasilis Editora. 672 pp.

Silveira, L.F. 2009. As aves da Reserva Biológica do Alto da Serra de Paranapiacaba: Uma revisão histórica do conhecimento ornitológico em uma reserva de Mata Atlântica do estado de São Paulo; pp. 1-16, in: M.I.M.S. Lopes, M. Kirizawa and M.M.R.F. Melo (ed.). Reserva Biológica do Alto da Serra de Paranapiacaba. São Paulo: Secretaria do Meio Ambiente.

Silveira, L. F. and F.C. Straube. 2008. Aves ameaçadas de extinção no Brasil; pp. 379-383, in: Machado, A. B. M., G.M. Drummond and A.P. Paglia (ed.). Livro vermelho da fauna brasileira ameaçada de extinção. Brasília: Ministério do Meio Ambiente (Biodiversidade 19).

Silveira, L.F. and A. Uezu. 2011. Checklist das aves do Estado de São Paulo, Brasil. Biota Neotropica 11: 1-28.
Silveira, L.F., G.A. Benedicto, F. Schunck and A.M. Sugieda. 2009. Aves; pp. 87-100, in: Bressan, P.M., M.C. Kierulff and A.M. Sugieda (org.). Fauna ameaçada de extinção no Estado de São Paulo: Vertebrados. São Paulo: Fundação Parque Zoológico de São Paulo e Secretaria do Meio Ambiente.

Simões, L.L. 2010. Guia de Aves Mata Atlântica paulista - Serra do Mar e Serra de Paranapiacaba. 1a edição. São Paulo: WWF Brasil. 133 pp.

Simpson, R., V. Cavarzere and E. Simpson. 2012. List of documented bird species from the municipality of Ubatuba, State of São Paulo, Brazil. Papéis Avulsos de Zoologia 52: 233-254.

Straube, F.C., A.Urben-Filho and C. Gatto. 2005. A avifauna do Parque Estadual do Cerrado (Jaguariaíva, Paraná) e a conservação do cerrado. Atualidades Ornitológicas 127: 29.

Ubaid, F. K., F. Maffei, G.M. Moya and R.J. Donatelli. 2011. Range extension for Buff-fronted Owl Aegolius harrisii in south-east Brazil. Bulletin of the British Ornithologists' Club 132(3): 175-179.

Willis, E.O. 1979. The composition on avian communities in remanescent woodlots in southern Brazil. Papéis Avulsos de Zoologia 33(1): 1-25.

Willis, E. O. and Y. Oniki. 2003. Aves do Estado de São Paulo. Rio Claro: Editora Divisa. 398 pp.

RECEIVED: March 2013

ACCEPTED: August 2013

Published ONLINE: February 2014

EDITORIAL RESPONSIBILITY: Vítor de Q. Piacentini 